\title{
Long-term hydrological and biogeochemical data for the Kuparuk River, North Slope, Alaska
}

\author{
Alexander Medvedeff ${ }^{1}$, Frances Iannucci ${ }^{2}$, and William Bowden ${ }^{1}$ \\ ${ }^{1}$ University of Vermont \\ ${ }^{2}$ University of Alaska Fairbanks
}

October 5, 2020

\section{KEYWORDS}

Arctic, benthic, catchment, climate change, discharge, long-term monitoring, nutrient enrichment, nutrients

\section{SITE DESCRIPTION and METHODS}

The upper Kuparuk River study site extends from its headwaters to five km below its intersection with the Dalton Highway. The majority of sampling takes place within five $\mathrm{km}$ of the road, approximately $190 \mathrm{~km}$ south of the Arctic Ocean on the North Slope of Alaska (68 $39^{\prime} \mathrm{N},-149^{\circ} 22^{\prime} \mathrm{E}$; Fig. 1). The river upstream of the intensely monitored reaches has a main channel length of $25 \mathrm{~km}$, drains an area of $143 \mathrm{~km}^{2}$, and has an average channel slope of $3.13 \%$ (Kriet et al., 1992). It is a clear-water, meandering, cobble-bottomed, poolriffle stream that is typically frozen from late September or early October until late May. The Kuparuk River has a spring flood (freshet) resulting from melting snow followed by lower flows in the summer. Summer water temperatures may reach $20^{\circ} \mathrm{C}$ and average 8 to $13^{\circ} \mathrm{C}$. The climate at the site is typical of Arctic regions, with a mean annual air temperature of about $-7^{\circ} \mathrm{C}$, low precipitation $(45 \%$ of the $20-40 \mathrm{~cm}$ of precipitation falls as snow), and extensive - though variable - snow cover for 7 to 9 months. During the summer the daily average air temperature is $7-12^{\circ} \mathrm{C}$ with the sun continuously above the horizon from mid-May to late July. Permafrost underlies the site to a depth of nearly $200 \mathrm{~m}$, with an active layer that thaws each summer to a depth between 30 and $50 \mathrm{~cm}$ (Bowden et al., 2014).

The Upper Kuparuk River Experiment

The Upper Kuparuk River Experiment (UKRE) began in 1983. The original goal of the UKRE was to determine the effects of adding the limiting nutrient, phosphorus, on primary productivity, insect communities, and fish growth in Arctic rivers. Phosphorus was added to the river continuously as phosphoric acid, via a peristaltic pump, from late June to mid-August, during the biologically active part of the Arctic year, and continued each year until the experimental enrichment ended in 2016. The original 1983 site of the phosphorus addition was designated as the $0 \mathrm{~km}$ reference point, with downstream stations assigned positive numbers and upstream stations given negative numbers based on distance from the $0 \mathrm{~km}$ location. The location of phosphorus addition was moved in 1985 to $0.59 \mathrm{~km}$ and in 1996 to $1.4 \mathrm{~km}$, to create two different "Recovery" reaches. In 2011, an additional dripper was placed at $0 \mathrm{~km}$ to resume enrichment of the reaches between $0 \mathrm{~km}$ and $1.4 \mathrm{~km}$. These re-fertilized areas were designated as the "ReFert" reaches. The stream reach from $0 \mathrm{~km}$ to $0.59 \mathrm{~km}$ (formerly "Recovery A") was designated as "ReFert-1", and the reach from $0.6 \mathrm{~km}$ to $1.39 \mathrm{~km}$ (formerly "Recovery B") was designated as "ReFert-2". Sites that received continuous enrichment throughout the course of the experiment were designated as the "Fertilized" reach and sites that were never enriched were designated as the "Reference" reach. We monitored physical, chemical, and biological variables at several riffle locations in each experimental reach, and collection of data from these sites has continued beyond 2016 to track the recovery of the formerly fertilized reaches. 


\section{Physical parameters}

Discharge and temperature data for the Kuparuk have been collected with different instruments as technology evolved over the $\sim 40$ years of this monitoring initiative. In the early years of the experiment, temperature and stream height were recorded manually each day. Since 1993, data loggers have measured stream temperature and stream height at regular intervals. Discharge measurements were taken at a variety of stage heights throughout the summer using a Gurley meter, Marsh McBirney portable water current meter, or SonTek FlowTracker. From 1993 through 2017, the University of Alaska Fairbanks's Water and Environmental Research Center (WERC) produced the official Kuparuk discharge record. High flow measurements were taken during spring freshet using an Acoustic Doppler Current Profiler (ADCP). Within season discharge was measured periodically by the Arctic LTER and at the end of the season, a consolidated rating curve was developed. Typically a pressure transducer (e.g. Onset HOBO U20) was used to provide continuous stage data. The consolidated rating curve was then applied to continuous stage height measurements to produce continuous discharge estimates. Temperature was recorded by a variety of means over the years, including thermometer measurements in early years, but more recently, Campbell data loggers, and HOBO pressure transducers.

\section{Chemical parameters}

Sampling of the Kuparuk River for sestonic and benthic nutrients typically occurred three times through the course of the summer, on a monthly basis. Each reach of the river was included in the monthly survey. For sestonic nutrients, samples were filtered on-site using a syringe, a $25 \mathrm{~mm}$ filter cassette, and $25 \mathrm{~mm} \mathrm{GF} / \mathrm{C}$ filters. Typically, we filtered $500 \mathrm{~mL}$ of river water through each filter, after which the filter was transferred with clean forceps into a Petri dish and dried at $60^{\circ} \mathrm{C}$ for 24 hours upon return to the field station. Two replicate filters were collected for analysis of particulate carbon, nitrogen and phosphorus. Filtered water samples were preserved according to their respective analysis. Ammonium, nitrate, and soluble reactive phosphorus (SRP) samples were frozen; total dissolved phosphorus (TDP), total dissolved nitrogen (TDN), dissolved organic carbon (DOC), and cation samples were acidified with hydrochloric acid and refrigerated; and alkalinity and anion samples were refrigerated. At the end of the season, all water samples and filters were returned to the Marine Biological Laboratory (MBL) in Woods Hole, Massachusetts until 2011 and thereafter to the University of Vermont (UVM) in Burlington, Vermont, for chemical analysis.

Epilithic algae were scrubbed from rock surfaces with a wire bristle brush into a known volume of water (the "scrubbate") and aliquots were taken to determine chlorophyll and particulate nutrient concentrations. From 1983 to 2004, epilithic algae was collected using the 2 x 2 rock scrub method, while the "whole rock" method has been used from 2004 to present (Peterson et al., 1993). A known volume of scrubbate from either method was filtered in-lab onto $25 \mathrm{~mm} \mathrm{GF} / \mathrm{C}$ filters. The chlorophyll filters were then frozen from 1-7 days, then placed in $10 \mathrm{ml}$ of $90 \%$ buffered acetone and extracted for 24 hours. Chlorophyll samples were read on a fluorometer at the field station. The filters for particulate $\mathrm{C}, \mathrm{N}$ and $\mathrm{P}$ and ash free dry mass were dried at $60{ }^{\circ} \mathrm{C}$ for 24 hours, then shipped and analyzed at MBL until 2011 and have since been analyzed at UVM.

\section{Biological parameters}

Through the course of the UKRE several biological parameters were monitored including macroinvertebrates, Arctic Grayling, and aquatic bryophyte cover.

Macroinvertebrates were collected using Surber samplers $(25 \mathrm{~cm}$ x $25 \mathrm{~cm}$ frame fitted with a $243 \mu \mathrm{m}$ mesh net). Two replicate samples of macroinvertebrates were collected on each date at each site. Samples were preserved in $4 \%$ formaldehyde. At the end of the field season, samples were shipped to Dr. Alex Huryn who verified identifications of all major species. Macroinvertebrates were removed by hand under 15X magnification, then identified and counted. All values are the mean of the replicates and have been converted to individuals per square meter.

Arctic Grayling (Thymallus arcticus), both adults and young-of-the-year (YOY), on the Kuparuk River were captured during the field season measured, weighed, and released. At the beginning of Arctic Grayling 
monitoring, fish were tagged with a colored, numbered floy tag, then in 1993, researchers started PIT tagging the Grayling. These PIT tags can be read with an antenna to track the migration of the grayling throughout the Kuparuk River system. The YOY are most typically caught using aquarium dip-nets, but have occasionally been caught via electrofishing in the past. Dr. Linda Deegan has managed the collection and analysis of this data.

A point transect method was used to monitor percent cover of dominant bryophytes and other macroalgae easily identifiable by eye in the experimental reaches of the Kuparuk River beginning in 1993 and to the present. Typically, point transects were done at least twice during the field season. Percent cover was recorded in specific riffle habitats and in some (early) years in specific pool habitats. The exact locations of transects within specific riffles differed slightly from year to year, but the specific riffles that were monitored remained constant. Typically at least 50 point observations were evenly spaced at intervals of 20 to 50 $\mathrm{cm}$ along each transect which spanned the entire width of the river. We collected observations along five transects at each sampling station resulting in at least 250 points per station. Cover type frequency was determined from the number of times each cover type was encountered, divided by the total number of points observed along each transect. The mean and standard deviation of 5 transects were used to characterize cover at a site. Sites within reaches (rather than transects within sites) are the replicable units. Only one cover type was recorded as present at any observation point. "Bare" recordings in the field notes were assumed to consist of an epilithic biofilm of diatoms and other microalgae as reported by Miller et al. (1992) and are recorded in the database here as "Epilithic algae".

\section{RESULTS}

The long-term enrichment of the Kuparuk River led to major shifts in primary producer species and production. After ten years of P-enrichment, the epilithic diatom dominated system was replaced by bryophytes, primarily Hygrohypnum spp., which led to a restructuring of the macroinvertebrate community but only subtle impacts on YOY and adult Arctic Grayling growth rates (Slavik et al., 2004).

Long-term monitoring of the Reference reach has revealed significant increases in flow-weighted mean concentrations of nitrate and significant decreases in flow-weighted mean concentrations of dissolved organic $\mathrm{N}$ and P (DON and DOP) over time (Fig. 2). These trends were noted recently by Kendrick et al. (2018) based on a shorter subset of the Kuparuk River record. Updated results from the entire ${ }^{\sim} 40$-season Upper Kuparuk River experiment are summarized in Iannucci, Beneš, Medvedeff, \& Bowden (In review) in this issue.

\section{DATA ACCESS}

All data is available through the Arctic LTER website (https://arc-lter.ecosystems.mbl.edu/arctic-lterstreams-and-rivers) under the "Data" section. Similar data of shorter duration is also available for Oksrukuyik Creek, as well as other Arctic streams near Toolik Field Station. All data from the Arctic LTER database are additionally available through the Environmental Data Initiative (EDI) data portal (https://portal.edirepository.org).

\section{REFERENCES}

Bowden, W. B., Peterson, B. J., Deegan, L. A., Huryn, A. D., Benstead, J. P., Golden, H., . . . Hobbie, J. E. (2014). Ecology of Streams of the Toolik Region. In J. E. Hobbie \& G. Kling (Eds.), Alaska's Changing Arctic: Ecological Consequences for Tundra, Streams, and Lakes(pp. 173-237). New York: Oxford Unviersity Press.

Iannucci, F., Beneš, J., Medvedeff, A., \& Bowden, W. B. (In review). Long-term catchment-based research and monitoring of an Arctic river: The Upper Kuparuk River Experiment. Hydrological Processes (This issue).

Kendrick, M. R., Huryn, A. D., Bowden, W. B., Deegan, L. A., Findlay, R. H., Hershey, A. E., . . . Schuett, E. B. (2018). Linking permafrost thaw to shifting biogeochemistry and food web resources in an arctic 
river. Global Change Biology, 24 (12), 5738-5750. doi:10.1111/gcb.14448

Kriet, K., Peterson, B. J., \& Corliss, T. L. (1992). Water and sediment export of the upper Kuparuk River drainage of the North Slope of Alaska.Hydrobiologia, 240 (1-3), 71-81. doi:10.1007/bf00013453

Miller, M. C., DeOliveira, P., \& Gibeau, G. G. (1992). Epilithic diatom community response to years of PO4 fertilization: Kuparuk River, Alaska (68 N Lat.). Hydrobiologia, 240 (1-3), 103-119.

Slavik, K., Peterson, B. J., Deegan, L. A., Bowden, W. B., Hershey, A. E., \& Hobbie, J. E. (2004). Long-term response of the Kuparuk River ecosystem to phosphorus fertilization. Ecology, 85 (4), 939-954.

Peterson, B. J., Deegan, L., Helfrich, J., Hobbie, J. E., Hullar, M., Moller, B., . . . Volk, G. (1993). Biological response of a tundra river to fertilization. Ecology, 74(3), 653-672.

\section{FIGURE LEGENDS}

Fig. 1 Map showing the Reference, Refert, and Fertilized reaches of the Kuparuk River on Alaska's North Slope. Locations of phosphorus addition sites are noted with numbered open circles.

Fig. 2 Discharge and flow-weighted average concentrations for nitrate $\left(\mathrm{NO}_{3}\right)$, soluble reactive phosphorus (SRP), dissolved organic carbon (DOC), dissolved organic nitrogen (DON), and dissolved organic phosphorus (DOP) in the Reference reach of upper Kuparuk River from 1983 to 2019.
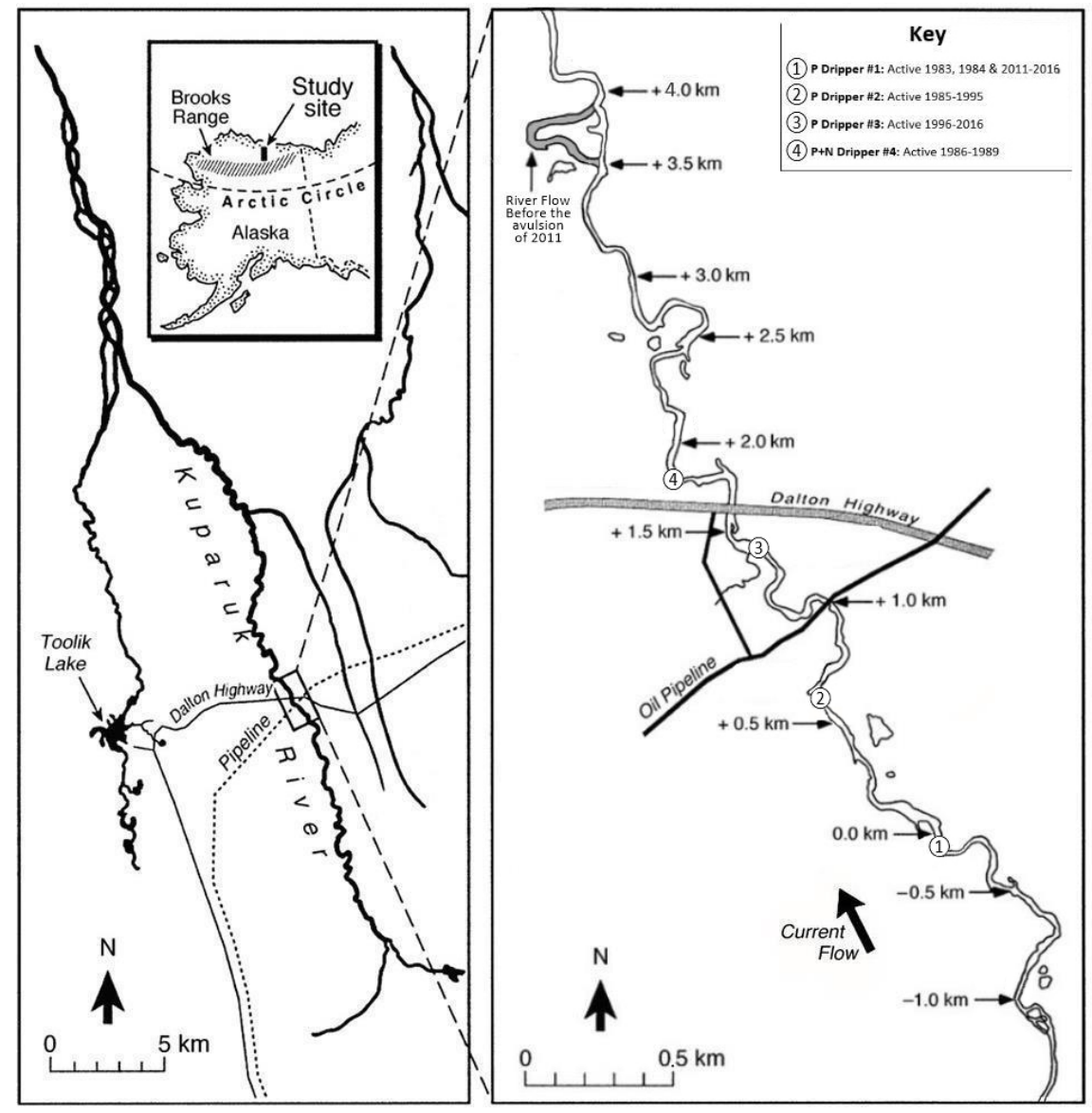
figures/Figure-2/Figure-2-eps-converted-to.pdf 